\title{
PENGARUH PERPUTARAN PERSEDIAAN DAN PERPUTARAN PIUTANG TERHADAP MODAL KERJA DAN PROFITABILITAS BERDASARKAN SIKLUS HIDUP PERUSAHAAN
}

\author{
Kartika Palupi $^{1 *}$, Mohamad Adam², Yuliani ${ }^{3}$, Marlina Widiyanti ${ }^{4}$ \\ ${ }^{1}$ Student of Master of Management, Sriwijaya University \\ Email: Kartikapalupi07@gmail.com \\ ${ }^{2}$ Dosen Fakultas Ekonomi Universitas Sriwijaya \\ Email:mr_adam2406@yahoo.com \\ ${ }^{3}$ Dosen Fakultas Ekonomi Universitas Sriwijaya \\ Email: Yulianisyapril@unsri.ac.id \\ ${ }^{4}$ Dosen Fakultas Ekonomi Universitas Sriwijaya \\ *penulis korespondensi
}

\begin{abstract}
ABSTRAK
Tujuan dalam penelitian adalah untuk melihat adanya pengaruh perputaran persediaan dan perputaran piutang terhadap modal kerja bersih dan profitabilitas berdasarkan siklus hidup perusahaan. Pengambilan sampel pada penelitian ini dengan metode purposive sampling berdasarkan kriteria yang ditetapkan dengan periode penelitian tahun 2014-2019 sedangkan objek penelitian adalah 97 perusahaan publik yang masuk dalam perusahaan manufaktur. Penelitian ini menggunakan metode regresi robust dengan software Eviews 9.0. Hasil pada penelitian adanya menunjukkan bahwa perputaran persediaan pada perusahaan tahap growth, mature, decline berpengaruh positif dan signifikan terhadap modal kerja bersih. Perputaran piutang pada perusahaan tahap growth, mature berpengaruh positif dan signifikan terhadap modal kerja bersih. Perusahaan pada tahap decline perputaran piutang tidak berpengaruh terhadap modal kerja bersih. Modal kerja bersih pada perusahaan tahap growth, mature, decline berpengaruh terhadap profitabilitas. Berdasarkan hasil pada penelitian ini memberikan impilikasi manajemen perusahaan adalah manajemen mampu dalam pengolahaan perputaran persediaan dan perputaran piutang secara efisien dan efektif sehigga mampu menghasilkan modal kerja bersih yang tingga dan berdampak pada profitablitas perusahaan.
\end{abstract}

Kata Kunci: Peputaran persediaan, Perputaran Piutang, Modal Kerja, Profitabilitas

\section{ABSTRACT}

The purpose of this research is to see the effect of inventory turnover and accounts receivable turnover on net working capital and company life cycle profitability. Sampling in this study using purposive sampling method, the criteria set by the research period 2014-2019, while the object of research is 97 public companies that are included in manufacturing companies. This study uses a robust regression method with Eviews 9.0 software. The results showed that it shows that inventory turnover at a growth stage company has a positive and significant effect on net working capital. Accounts receivable turnover at growth stage companies has a positive and significant effect on net working capital. Companies in the decline stage of accounts receivable turnover have no effect on net working capital. Net working capital at a company with a growth stage, maturity, decline affects profitability. Based on the results of this study, the implication of company management is that management is able to process inventory turnover and accounts receivable turnover efficiently and effectively so as to be able to produce high net working capital and have an impact on company profitability.

Keywords: Inventory Turnover, Accounts Receivable Turnover, Working Capital, Profitability

\section{PENDAHULUAN}

\section{Latar Belakang}

Perusahaan dituntut dalam melakukan perkembangan dikarenakan persaingan antar perusahaan di Indoensia semakin sangat kompetitif. Persaingan ini juga terjadi pada perusahaan sejenis sehingga menuntut selalu melakukan perubahan menjadi lebih baik agar unggul dalam setiap persaingan dunia usaha. Menjalani aktivitasnya, perusahaan pasti diarahkan untuk mencapai 
tujuan. Menurut Wijaya, (2012) umumnya tujuan utama perusahaan untuk menghasilkan laba maksimal. Perusahaan berhasil dalam mencapai tujuaannya dapat dilihat dari berbagai aspek satu diantara yang ada adalah aspek profitabilitas Riyanto, et al., (2019). Keuntungan yang didapat oleh perusahaan merupakan indikator keberhasilan dan dapat menjaga keberlangsungan hidup perusahaan. Perusahaan menjaga keberlangsungan hidup biasanya menggunakan dana yang disebut dengan modal kerja.

Brigham \& Houston, (2014: 258) modal kerja merupakan bentuk dari investasi dan digunakan dalam operasional bagi perusahaan. Modal kerja merupakan hal penting bagi perusahaan untuk bisa memenuhi semua kewajiban lancar sehingga tidak berefek dimasa akan datang. Menurut Ross et al., (2013) modal kerja bersih adalah lebihnya aktiva lancar terhadap hutang lancar. Menurut Anggarani \& Ficilia, (2014) menyatakan selisih yang tinggi diantara aktiva lancar dengan hutang lancar maka dapat dikatakan perusahaan sangat tepat dalam pengelolahaan modal kerja sehingga dapat meningkatkan profitabilitas perusahaan. Menurut Tnius, (2018) profitabilitas adalah suatu parameter perusahaan dalam meningkatkan keuntungan pada satu periode. Profitabilitas dapat dihitung dengan cara membandingkan jumlah laba bersih dalam suatu periode dengan jumlah aktiva Reimeinda et al., (2016).

Lestiowati \& Pd, (2018) perputaran persediaan menggambarkan jumlah dana yang tersimpan dalam persediaan dan mengalami pemutaran sehingga dapat kembali lagi menjadi kas bagi perusahaan. Besar kecilnya perputaran bagi persediaan akan menunjukkan tingkat modal kerja bersih yang dapat dipeoleh oleh perusahaan atau yang dapat dipertahankan bagi perusahaan. Sambouw, (2011). Pada penelitian ini menggunakan rasio inventory turnover, dengan harga pokok penjualan dan membagi jumlah rata - rata persediaan Ross et al., (2013).

Perputaran piutang menurut Hardianto, (2014) menunjukkan berapa kali piutang yang dapat tertagih dengan cara perbandingan penjualan dibagi dengan rata - rata piutang. Menurut (Sambouw, 2011) yang menyatakan bahwa perputaran piutang yang efisien dapat menambah pendapatan sehingga akan menambah modal kerja bersih yang diperoleh oleh perusahaan. Penelitian ini menggunakan rasio receivables turnover dengan rumus penjuaalan dibagi dengan rata - rata piutang. Menurut Ross et al, (2013: 810) perhitungan perputaran piutang dapat dihitung dengan penjualan dibagi dengan rata - rata piutang dengan asumsi semua penjualan adalah penjualan kredit. Menurut Frielinghaus et al., (2005) modal kerja perusahaan sangat erat kaitannya dengan tahap siklus hidup perusahaan. Menurut Gup \& Agrrawal, (1996) bahwa siklus hidup perusahaan dibagi menjadi empat berdasarkan data penjualan yaitu: start-up, growth, mature dan decline.

Penelitian yang dilakukan oleh Azizah, (2017) menyatakan bahwa perputaran persediaan berpengaruh signifikan terhadap modal kerja bersih. Bertolak belakang dengan penelitian yang dilakukan Rahayu et al., (2017) bahwa tidak adanya pengaruh perputran persediaan terhadap modal kerja bersih. Selajutnya penelitian tentang perputran piutang dilakukan oleh S. Rahayu et al., (2017), Rao \& Gaglani, (2014), dan Sulviani, (2014) menyatakan bahwa perputaran piutang berpengaruh signifikan terhadap modal kerja bersih. Hasil penelitian tidak sejalan dengan penelitian Wahyudi, (2013) yang menyatakan perputaran piutang tidak memiliki pengaruh terhadap modal kerja bersih.

Penelitian yang bertujuan untuk mengetahui hubungan modal kerja bersih terhadap profitabilitas dilakukan oleh Tnius, (2018), Herlina \& Nursanah, (2015), dan Supriadi \& Puspitasari, (2012) dengan hasil yang menyatakan bahwa modal kerja bersih memiliki pengaruh terhadap ROA. 
Hasil yang bertentangan dengan penelitian yang dilakukan oleh Reimeinda et al., (2016) bahwa tidak memiliki adanya pengaruh modal kerja bersih terhadap profitabilitas

Dilihat dari penelitian terdahulu yang telah diuraikan, yang mendorong peneliti untuk mengadaptasi penelitian yang dilakukan dengan mengambil sampel berupa perusahaan manufaktur yang terdaftar di Bursa Efek Indonesia dari tahun 2014 sampai tahun 2019. Berdasarkan latar belakang yang telah dijelaskan maka penulis ingin mengangkat permasalahan "Pengaruh Perputaran Persediaan Dan Perputaran Piutang Terhadap Modal Kerja dan Profitabilitas Berdasarkan Siklus Hidup Perusahaan"

\section{Rumusan Masalah}

Berdasarkan pendahuluan yang dijabarkan, ditarik rumusan masalah pada penelitian ini adalah:

1. Apakah terdapat pengaruh perputaran persediaan dan perputaran piutang terhadap modal kerja bersih dan berdampak pada profitabilitas berdasarkan siklus hidup pada perusahaan manufaktur yang terdaftar di BEI?

\section{LANDASAN TEORI}

Modal kerja bersih menurut Herlina dan Nursanah, (2015) berpendapat bahwa modal kerja yang dikaitkan dengan jumlah dari hutang lancar yang harus segera dibayar. Dimana aktiva lancar ini harus disediakan dalam memenuhi hutang lancar dan tidak boleh dipergunakan untuk membiayai operasi. Modal kerja bersih menunjukkan tersedianya aktiva lancar yang lebih besar dibandingkan dengan hutang lancar hal ini dapat menunjukkan tingkat likuiditas perusahaan serta dapat menjamin kelangsungan usaha dimasa akan datang Wahyudi, (2013).

Menurut Brigham \& Houston, (2014) rasio profitabilitas suatu rasio yang dapat menggambarkan kemampuan dari perusahaan dalam mendapatkan laba. Profitabilitas sebagai ukuran kinerja keuangan perusahaan mencerminkan tingkat sukses dalam jangka waktu tertentu Yuliani et al, (2018). Salah satu rasio profitabilitas adalah return On Assets (ROA) yaitu penilaian profitabilitas terhadap total assets dengan cara membandingkan laba setelah pajak dengan rata rata total aktiva. Rasio ini menunjukkan efektivitas perusahaan dalam mengelola aktiva baik dari modal sendiri atau pinjaman.

Perputaran persediaan menurut Gunawan \& Tjun, (2014) menunjukkan seberapa cepat proses persediaan berubah menjadi kas. Jika tingkat perputaran persediaan semakin tinggi maka semakin efisien perusahaan melaksanakan operasionalnya Azizah, (2017). Menurut Ross et al, (2013) rasio perputaran persediaan dapat dihitung dengan HPP di bagi dengan rata - rata persediaan.

Perputaran piutang menurut Ross et al, (2013: 53) memberikan gambaran bahwa seberapa banyak piutang dapat terjadi hingga piutang tersebut dapat tertagih kemudian menjadi kas bagi perusahaan tersebut pada satu periode. Tinggi atau rendahnya perputaran piutang akan dipengaruhi oleh sayarat yang telah diberikan oleh perusahaan sehingga akan berakibat pada lamanya piutang dapat tertagih Sofyan \& Saifi, (2019). Menurut Ross et al, (2013: 810) perhitungan perputaran piutang bisa dihitung dengn perbandingan penjualan terhadap rata - rata piutang dengan asumsi bahwa penjualan merupakan penjualan bersifat kredit.

\section{METODE PENELITIAN}

Ruang lingkup pada penelitian ini membahas tentang dua variabel independen yaitu perputaran persediaan $\left(\mathrm{X}_{1}\right)$ dan perputaran piutang $\left(\mathrm{X}_{2}\right)$ dan dua variabel dependen yaitu modal kerja bersih 
$\left(\mathrm{Y}_{1}\right)$ dan profitabilitas $\left(\mathrm{Y}_{2}\right)$ berdasarkan siklus hidup perusahaan pada perusahaan manufaktur yang terdaftar di BEI pada tahun 2014 - 2019. Objek pada penelitian yaitu sebanyak 97 perusahaan. Kemudian Objek penelitian dikelompokkan berdasarkan siklus hidup perusahaan berdasarkan data penjualan dan dihitung tingkat pertumbuhan penjualan Gup \& Agrrawal, (1996)

Tabel 1 Siklus Hidup Perusahaan berdasarkan data penjualan Sumber : Gup \& Agrrawal, 1996

\begin{tabular}{cc}
\hline Siklus Hidup & Rata - rata penjualan \\
\hline Start up & $>50 \%$ \\
Growth & $10 \%-49,9 \%$ \\
Mature & $0 \%-9,9 \%$ \\
Decline & $<0 \%$ \\
\hline
\end{tabular}

\section{HASIL DAN PEMBAHASAN}

\section{Statistik Deskriptif}

Suatu analisis data yang mengambarkan keadaan data berdasarkan nilai terendah, tertinggi, mean dan standar deviasi.

Tabel 2. Statistik Deskriptif Pada Tahap Growth (n=29)

Sumber: Data yang diolah menggunakan Eviews9

\begin{tabular}{lllll}
\hline Variabel & Min & Max & Rata - rata & $\begin{array}{l}\text { Standar } \\
\text { Deviasi }\end{array}$ \\
\hline Perputaran Persediaan & 0.004439 & 144.4260 & 8.287123 & 15.63046 \\
Perputaran Piutang & 0.378099 & 133.9128 & 9.780698 & 14.08338 \\
Modal Kerja Bersih & -4590669. & 26822406 & 1393116. & 4202883 \\
Profitabilitas & -15.84000 & 72.00000 & 6.341759 & 10.53166 \\
\hline
\end{tabular}

Tabel 3. Statistik Deskriptif Pada Tahap Mature (n=47)

Sumber: Data yang diolah menggunakan Eviews 9

\begin{tabular}{lllll}
\hline Variabel & Min & Max & Rata - rata & $\begin{array}{l}\text { Standar } \\
\text { Deviasi }\end{array}$ \\
\hline Perputaran Persediaan & 0.663829 & 19.02607 & 4.585159 & 2.534451 \\
Perputaran Piutang & 0.497853 & 63.35187 & 7.286732 & 5.723439 \\
Modal Kerja Bersih & -7142103. & 29096000 & 2228368. & 5418202 \\
Profitabilitas & -22.01000 & 53.00000 & 6.241206 & 8.545215 \\
\hline
\end{tabular}

Tabel 4. Statistik Deskriptif Pada Tahap Decline $(\mathrm{n}=21)$

Sumber: Data yang diolah menggunakan Eviews 9

\begin{tabular}{lllll}
\hline Variabel & Min & Max & Rata - rata & $\begin{array}{l}\text { Standar } \\
\text { Deviasi }\end{array}$ \\
\hline Perputaran Persediaan & 0.004439 & 144.4260 & 8.287123 & 15.63046 \\
Perputaran Piutang & 0.378099 & 133.9128 & 9.780698 & 14.08338 \\
Modal Kerja Bersih & -4590669. & 26822406 & 1393116. & 4202883 \\
Profitabilitas & -15.84000 & 72.00000 & 6.341759 & 10.53166 \\
\hline
\end{tabular}


Uji Asumsi klasik

Normalitas

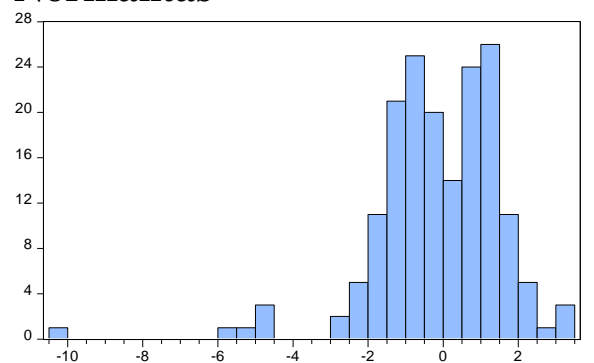

(a)

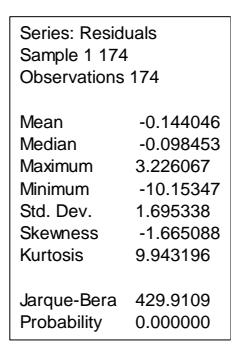

Probability $\quad 0.000000$

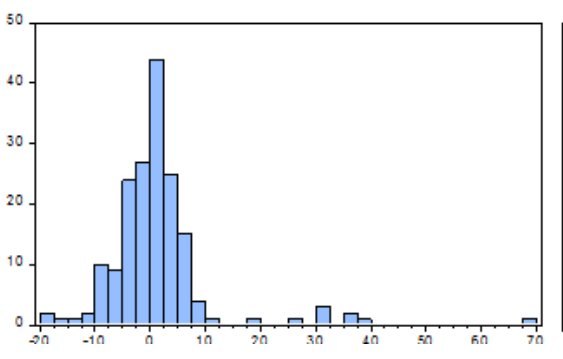

(b)

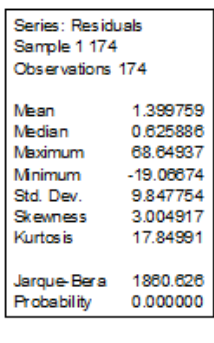

800.628

Gambar 1. (a) Uji Normalitas Data Perputaran Persediaan dan Perputaran Piutang Terhadap Modal Kerja Bersih-Growth Stage (b) Uji Normalitas Data Modal Kerja Bersih Terhadap

Profitabilitas (ROA) - Growth Stage

Sumber: Data yang diolah menggunakan Eviews 9

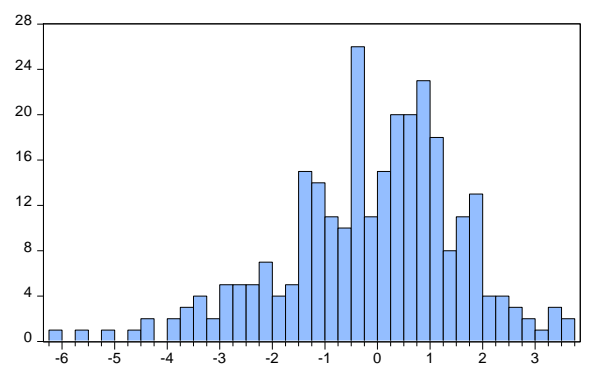

(a)

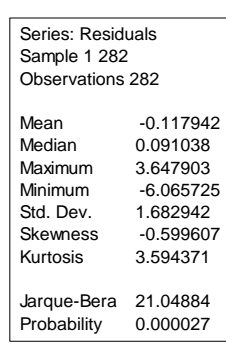

ata

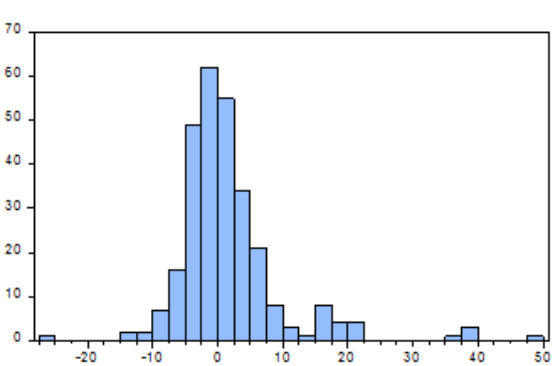

(b)

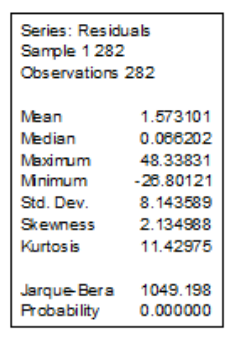

0.000000

Gambar 2. (a) Uji Normalitas Data Perputaran Persediaan dan Perputaran Piutang Terhadap Modal Kerja Bersih-Mature Stage (b) Uji Normalitas Data Modal Kerja Bersih Terhadap

Profitabilitas (ROA) - Mature Stage

Sumber: Data yang diolah menggunakan Eviews9

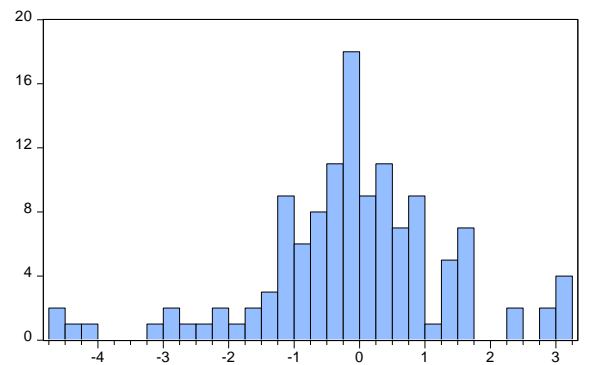

(a)

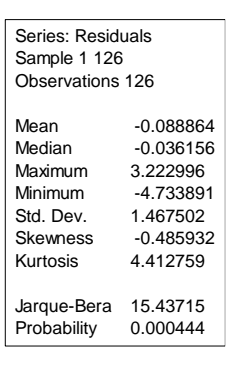

(1)

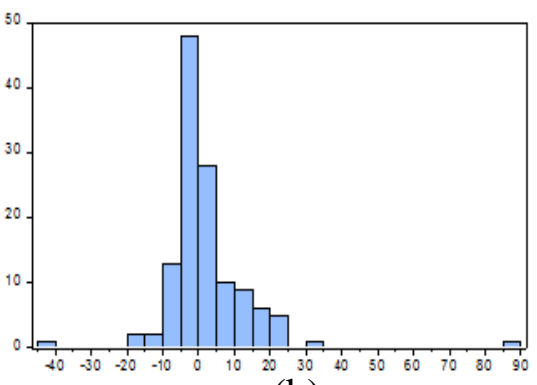

(b)

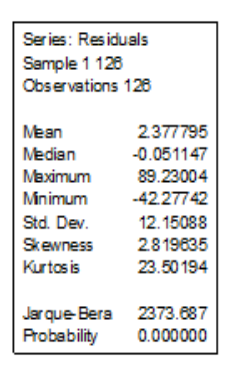

Jarque Bers $\quad 2373.687$
Probability

Gambar 3. (a) Uji Normalitas Data Perputaran Persediaan dan Perputaran Piutang Terhadap Modal Kerja Bersih-Mature Stage (b) Uji Normalitas Data Modal Kerja Bersih Terhadap

Profitabilitas (ROA) - Mature Stage

Sumber: Data yang diolah menggunakan Eviews 9

Dari semua histogram diatas maka dapat dilihat nilai probability lebih kecil dari 0,05 hal ini disimpulkan bahwa data tidak berdistribusi normal. Menurut Ryan, (1997) apabila ketika uji normalitas tidak memenuhi maka dapat dilakukan analisis regresi robust yang tahan terhadap masalah asumsi klasik. Regresi metode robust adalah regresi dapat digunakan pada data yang digunakan tidak normal sehingga akan mempengaruhi terhadap model yang dihasilkan Chen, 
(2015). Apabila uji asumsi tidak dapat terpenuh maka apabila tetap menggunakan metode OLS dalam mengestimasi parameter regresi akan menghasilkan hasil yang tidak baik Sungkawa, (2009). Oleh karena itu untuk mengatasi hal tersebut diperlukan metode lain agar analisis data dengan adanya data pencilan tetap tahan terhadap asumsi yang diterapkan pada analisis datanya Rousseeuw \& Leroy, (1987).

\section{Analisis Regresi Robust}

Regresi robust adalah suatu metode regresi yang digunakan apabila distribusi dari error menunjukkan tidak normal atau terdapat beberapa outlier yang berpengaruh terhadap model Nurdin et al.,( 2014). Menurut Rahman \& Widodo, (2018) metode ini merupakan alat penting untuk menganalisis data yang dipengaruhi oleh outlier sehingga dapat menghasilkan model yang robust atau resistance terhadap outlier. Regresi robust digunakan untuk mendeteksi pencilan dan memberikan hasil yang resisten terhadap adanya pencilan (Chen, 2002).

Tabel 5 Hasil Regresi Model 1

Sumber: Data yang diolah menggunakan Eviews 9

\begin{tabular}{llll}
\hline \multicolumn{1}{c}{ Variabel } & \multicolumn{3}{c}{ Coefficient } \\
\cline { 2 - 4 } & Growth $(\mathbf{n = 1 7 4})$ & Mature $(\mathbf{n = 2 8 3})$ & Decline $(\mathbf{n = 1 2 6})$ \\
\hline Konstanta & 9.887015 & 9.788844 & 10.43117 \\
Per_Persediaan & 1.152982 & 1.152982 & 1.062991 \\
Per_Piutang & 0.123706 & 0.123706 & 0.374542 \\
\hline
\end{tabular}

Berdasarkan tabel 5 hasil regresi model 1 yaitu menjelaskan pengaruh perputran persediaan dan perputaran piutang terhadap modal kerja bersih dengan persamaan sebagai berikut:

Modal Kerja Bersih $\left(\mathrm{Y}_{1}\right)=\alpha_{1}+\beta$ Perputaran Persediaan $\left(\mathrm{X}_{1}\right)+\beta$ Perputaran Piutang $\left(\mathrm{X}_{2}\right)+\mathrm{e}$

Tabel 6 Hasil Regresi Model 2

Sumber: Data yang diolah menggunakan Eviews9

\begin{tabular}{llll}
\hline \multicolumn{1}{c}{ Variabel } & \multicolumn{3}{c}{ Coefficient } \\
\cline { 2 - 4 } & Growth $(\mathbf{n}=174)$ & Mature $(\mathbf{n = 2 8 3})$ & Decline $(\mathbf{n = 1 2 6})$ \\
\hline Konstanta & -12.71747 & 6.403488 & -9.280030 \\
\hline $\begin{array}{l}\text { Modal Kerja } \\
\text { Bersih }\end{array}$ & 1.596339 & 0.982979 & 1.120560 \\
\hline
\end{tabular}

Berdasarkan tabel 6 diatas yaitu menjelaskan modal kerja bersih terhadap profitabilitas. Dengan model regresi sebagai berikut:

$$
\text { Profitabilitas }(\mathrm{Y} 2)=\alpha_{1}+\beta \text { Modal Kerja Bersih }\left(\mathrm{Y}_{1}\right)+\mathrm{e}
$$

\section{Uji Hipotesis \\ Uji Parsial (Uji T)}

Tabel 7 Uji T Model 1

Sumber: Data yang diolah menggunakan Eviews9

\begin{tabular}{lllll}
\hline \multicolumn{1}{c}{ Uji T } & \multicolumn{3}{c}{ Nilai Prob } & Keputusan \\
\cline { 2 - 5 } & $\begin{array}{l}\text { Growth } \\
(\mathbf{n = 1 7 4 )}\end{array}$ & $\begin{array}{l}\text { Mature } \\
(\mathbf{n = 2 8 3})\end{array}$ & $\begin{array}{l}\text { Decline } \\
(\mathbf{n = 1 2 6})\end{array}$ & \\
\hline Per_Persediaan & 0.0119 & 0.0058 & 0.0043 & $\begin{array}{l}\text { Signifikan } \\
\text { Per_Piutang }\end{array}$ \\
0.0000 & 0.0000 & 0.2061 & $\begin{array}{l}\text { Signifikan, Kecuali } \\
\text { tahap Decline tidak } \\
\text { signifikan }\end{array}$ \\
\hline
\end{tabular}


Tabel 8 Hasil Uji T Model 2

Sumber: Data yang diolah menggunakan Eviews 9

\begin{tabular}{cllll}
\hline \multirow{2}{*}{ Uji T } & \multicolumn{3}{c}{ Nilai Prob } & Keputusan \\
\cline { 2 - 4 } & $\begin{array}{c}\text { Growth } \\
(\mathbf{n = 1 7 4})\end{array}$ & $\begin{array}{l}\text { Mature } \\
(\mathbf{n = 2 8 3})\end{array}$ & $\begin{array}{l}\text { Decline } \\
(\mathbf{n = 1 2 6})\end{array}$ & \\
\hline Modal Kerja Bersih & 0.0000 & 0.0000 & 0.0014 & Signifikan \\
\hline
\end{tabular}

Berdasarkan hasil uji $\mathrm{T}$ maka didapat untuk model 1 secara parsial perputaran persediaan berpengaruh terhadap modal kerja bersih pada setiap siklus hidup perusahaan. Sedangkan perputaran piutang memiliki pengaruh pada modal kerja bersih kecuali tahap decline.. Pada model 2 bahwa modal kerja bersih memiliki pengaruh terhadap profitabilitas.

\section{Uji F}

Tabel 9 Hasil Uji F Model 1

Sumber: Data yang diolah menggunakan Eviews9

\begin{tabular}{lllll}
\hline & \multicolumn{3}{c}{ Nilai Prob (F-Statistic) } & Keputusan \\
\cline { 2 - 4 } & $\begin{array}{l}\text { Growth } \\
(\mathbf{n = 1 7 4})\end{array}$ & $\begin{array}{l}\text { Mature } \\
(\mathbf{n = 2 8 3})\end{array}$ & $\begin{array}{l}\text { Decline } \\
(\mathbf{n = 1 2 6})\end{array}$ & \\
\hline Uji F & 0.000000 & 0.000000 & 0.004724 & Signifikan \\
\hline
\end{tabular}

Tabel 10 Hasil Uji F Model 2

Sumber: Data yang diolah menggunakan Eviews 9

\begin{tabular}{lllll}
\hline & \multicolumn{3}{c}{ Nilai Prob (F-Statistic) } & Keputusan \\
\cline { 2 - 4 } & $\begin{array}{l}\text { Growth } \\
(\mathbf{n = 1 7 4 )}\end{array}$ & $\begin{array}{l}\text { Mature } \\
(\mathbf{n = 2 8 3})\end{array}$ & $\begin{array}{l}\text { Decline } \\
(\mathbf{n = 1 2 6})\end{array}$ & \\
\hline Uji F & 0.000000 & 0.000000 & 0.001420 & Signifikan \\
\hline Sumber: Data yang diolah menggunakan Eviews & &
\end{tabular}

Berdasarkan tabel 9 diatas dapat disimpulkan secara simultan perputaran persediaan dan perputaran piutang sama - sama berpengaruh signifikan pada modal kerja bersih pada setiap siklus hidup perusahaan. Tabel 10 dapat disimpulkan bahwa modal kerja bersih memiliki pengaruh sgnifikan pada profitabilitas untuk setiap siklus hidup perusahaan.

\section{Uji Koefisien Determinasi}

Tabel 11 Uji R² Model 1

Sumber: Data yang diolah menggunakan Eviews9

\begin{tabular}{llll}
\hline & $\begin{array}{l}\text { Growth } \\
(\mathbf{n = 1 7 4})\end{array}$ & $\begin{array}{l}\text { Mature } \\
(\mathbf{n = 2 8 3})\end{array}$ & $\begin{array}{l}\text { Decline } \\
(\mathbf{n = 1 2 6})\end{array}$ \\
\hline $\mathrm{Uji} \mathrm{R}^{2}$ & 0.192301 & 0.200322 & 0.110829 \\
\hline
\end{tabular}

Tabel 12 Uji R ${ }^{2}$ Model 2

Sumber: Data yang diolah menggunakan Eviews 9

\begin{tabular}{llll}
\hline & $\begin{array}{l}\text { Growth } \\
(\mathbf{n = 1 7 4})\end{array}$ & $\begin{array}{l}\text { Mature } \\
(\mathbf{n = 2 8 3})\end{array}$ & $\begin{array}{l}\text { Decline } \\
(\mathbf{n = 1 2 6})\end{array}$ \\
\hline $\mathrm{Uji} \mathrm{R}^{2}$ & 0.284835 & 0.149036 & 0.082962 \\
\hline
\end{tabular}


Koefisien determinasi atau $\mathrm{R}^{2}$ sebuah uji hipotesis yang mengambarkan kemampuan sebuah model sehingga dapat mendeskripsikan variable dependen. Pada tabel 11 disimpulkan perputaran persediaan dan perputaran piutang terhadap modal kerja bersih sebesar 19\% tahap growth, $20 \%$ tahap mature dan $11 \%$ tahap decline. Hasil pada tabel 12 sebesar 28\% tahap growth, $14 \%$ tahap mature dan $8 \%$ tahap decline

\section{Pengaruh Perputaran Persediaan terhadap Modal Kerja Bersih}

Berdasarkan hasil yang didapat pada pengolahan data perusahaan pada tahap growth didapat hasilnya bahwa H1 diterima. Dalam pengujian regresi bahwa perputaran persediaan memiliki nilai prob. sebesar 0.0119 dan nilai coefficient sebesar 0.682133 .

Pada tahap mature, didapat hasilnya bahwa perputaran persediaan berpengaruh signifikan dan berarah positif terhadap modal kerja bersih sehingga $\mathrm{H} 1$ diterima. Nilai prob. sebesar 0.0058 dan nilai coefficient sebesar 1.152982. Maka semakin cepat perputaran persediaan maka semakin tinggi berdampak terhadap peningkatan modal kerja bersih

Pada tahap decline, perputaran persediaan berpengaruh signifikan dan berarah positif terhadap modal kerja bersih sehingga H1 diterima. Nilai prob. sebesar 0.0043 dan nilai coefficient sebesar 1.062991. Maka semakin cepat perputaran persediaan maka semakin tinggi berdampak terhadap peningkatan modal kerja bersih.

Perputaran persediaan pada tahap growth memiliki nilai prob. lebih besar dibandingkan pada tahap mature dan decline. Pada tahap growth, perusahaan mengalami kenaikan penjualan maka perusahaan mengambil keputusan dalam meningkatkan persediaan. Dikarenakan tingkat penjualan yang tinggi pada tahap growth maka nilai perputaran persediaan lebih tinggi dibandingkan tahap lainnya sehingga berefek pada modal kerja bersih perusahaan. Nilai prob pada tahap mature mengalami penurunan dibandingkan tahap growth hal ini dikarena pada tahap ini adanya pengaruh tingkat penjualan yang mengalami kejenuhan sehingga tingkat perputaran persediaan mengalami penurunan dan berpengaruh pada modal kerja bersih. Pada tahap decline perputaran persediaan memiliki nilai prob yang rendah dikarenakan pada tahap ini perusahaan mengalami penurunan penjualan sehingga perusahaan mengurangi jumlah stock persediaan dan berdampak rendahnya tingkat perputaran persediaan.

Berdasarkan hasil penelitian menyatakan bahwa $\mathrm{H} 1$ diterima terdapat pengaruh perputaran persediaan terhadap modal kerja bersih. Sehingga dengan semakin meningkat perputaran persediaan maka akan diikuti dengan meningkatnya modal kerja bersih. Hal ini sejalan dengan Menurut Rahayu et al., (2017) Perputaran persediaan sangat berpengaruh besar atau kecilnya modal kerja bersih pada perusahaan.

Tingkat rendah atau tinggi peputaran persediaan akan mempengaruhi modal kerja bersih pada perusahaan. Dikarenakan adanya modal yang tertanam pada persediaan sehingga dana tersebut tidak dapat membayar hutang lancar perusahaan. Hal ini dikarenkaan peningkatan perputaran persediaan akan menunjukkan baknya perusahaan dalam mengelola persediaan sehingga dana yang tertanam dalam persediaan semakin sedikit dan dapat mengurangi biaya akibat penumpukan persediaan. Apabila tingkat perputaran rendah maka perusahaan akan mendapatkan resiko yang bertambahnya biaya tambahan sehingga akan mempengaruhi modal kerja bersih peusahaan Azizah, (2017). Menurut Ross et al., (2013) dana yang terikat dalam persediaan maka perusahaan tidak dapat memenuhi melunasi kewajiban lancarnya. 
Penelitian ini didukung oleh Azizah, (2017), Sambouw, (2011) Sertinaria, (2007) menguji hubungan perputaran persediaan dengan modal kerja bersih yang menyatakan bahwa perputaran persediaan berpengaruh signifikan dan positif terhadap modal kerja bersih. Hasil yang sama juga didapat pada penelitian, yaitu adanya pengaruh perputaran persediaan secara signifikan dan positif terhadap modal kerja bersih.

\section{Pengaruh Perputaran Piutang terhadap Modal Kerja Bersih}

Berdasarkan hasil yang didapat pada pengolahan data perusahaan pada tahap growth didapat hasilnya bahwa $\mathrm{H} 2$ diterima. Dimana perputaran piutang berpengaruh signifikan dan berarah positif terhadap modal kerja bersih. Dalam pengujian regresi bahwa perputaran piutang memiliki nilai prob. sebesar 0.0000 dan nilai coefficient sebesar 2.169804 .

Pada tahap mature, perputaran piutang berpengaruh signifikan dan berarah positif terhdap modal kerja bersih sehingga $\mathrm{H} 2$ diterima. Nilai prob. sebesar 0.0000 dan nilai coefficient sebesar 0.123706. Maka semakin cepat perputaran piutang maka semakin tinggi berdampak terhadap peningkatan modal kerja bersih

Pada tahap decline, perputaran piutang tidak signifikan dan tidak berarah positif terhadap modal kerja bersih sehingga $\mathrm{H} 2$ ditolak dengan nilai prob. sebesar 0.2061. Maka perputaran piutang tidak berpengaruh dan berdampak terhadap peningkatan modal kerja bersih.

Dari hasil yang didapat perputaran piutang memiliki nilai berbeda pada setiap tahapnya terhadap modal kerja bersih. Jika dibandingkan nilai pada tahap growth lebih kecil dibandingkan pada tahap mature. Hal ini dikarenakan apabila perusahaan pada tahap mature maka perusahaan sudah berada pada titik puncak penjualan sehingga apabila penjualan dilakukan dalam bentuk kredit maka akan terproses cepat tertagih dan kembali menjadi kas. Pada tahap decline, perputaran piutang tidak signifikan terhadap modal kerja bersih karena perusahaan mengalami kemunduran dalam penjualan hal ini berakibat tidak adanya piutang yang dapat tertagih sehingga bernilai negative terhadap modal kerja bersih.

Menurut Rahayu et al., (2017) perputaran piutang memperlihatkan jumlah proses piutang dapat menjadi kas kembali bagi perusahaan. Dengan perputaran piutang yang baik dan cepat maka kas perusahaan akan cepat bertambah sehingga perusahaan dapat memenuhi hutang lancarnya. Bila perusahaan dapat memenuhi hutang lancarnya maka perusahaan dapat mempertahankan modal kerja bersih. Tinggi rendahnya perputaran piutang akan mempengaruhi besar atau kecilnya dana yang diinvestasikan dalam piutang. Semakin tinggi perputaran piutang menjelaskan bahwa semakin baik dalam penagihan piutang sehingga dana pada piutang dapat digunakan perusahaan memenuhi hutang lancar sehingga meningkatnya modal kerja bersih perusahaan Horne dan John M. Wachowicz, (2013).

Penelitian didukung oleh S. Rahayu et al., (2017), Rao \& Gaglani, (2014), dan Sulviani, (2014) menguji hubungan perputaran piutang dengan modal kerja bersih yang menyatakan bahwa perputaran piutang berpengaruh signifikan dan positif terhadap modal kerja bersih. Hasil yang sama juga didapat pada penelitian, yaitu adanya pengaruh perputaran piutang secara signifikan dan positif terhadap modal kerja bersih. Sedangkan pada tahap decline, perputaran piutang tidak berpengaruh terhadap modal kerja bersih didukung dengan penelitian oleh Wahyudi, (2013) yang menyatakan bahwa perputaran piutang tidak berpengaruh signifikan terhadap modal kerja bersih. 


\section{Pengaruh Modal Kerja Bersih terhadap Profitabilitas.}

Berdasarkan hasil pengolahan data perusahaan pada tahap growth didapat bahwa H3 diterima, maka disimpulkan bahwa modal kerja bersih berpengaruh positif dan signifikan terhadap profitabilitas. Dalam pengujian regresi bahwa modal kerja bersih memiliki nilai prob. sebesar 0.0000 dan nilai coefficient sebesar 1.596339 .

Pada tahap mature, modal kerja bersih berpengaruh positif dan signifikan terhadap profitabilitas sehingga hipotesis 3 (H3) diterima dengan nilai prob. sebesar 0.0000 dan nilai coefficient sebesar 0.982979. Maka semakin cepat modal kerja bersih maka semakin tinggi berdampak terhadap peningkatan profitabilitas.

Pada tahap decline, modal kerja bersih berpengaruh positif dan signifikan terhadap profitabilitas sehingga H3 diterima dengan nilai prob. sebesar 0.0014 dan nilai coefficient sebesar 1.120560. Maka meningkat modal kerja bersih maka berpengaruh dan berdampak terhadap peningkatan profitabilitas.

Hasil analisis regresi pada tahap growth, mature dan decline diperoleh bahwa hipotesis 3 diterima dengan koefisien regresi bertanda positif dan berpengaruh signifikan maka dapat disimpulkan semakin tinggi modal kerja bersih maka semakin tinggi berdampak terhadap peningkatan ROA. Nilai prob. pada tahap growth dan mature sama - sama memiliki nilai sebesar 0.0000 yang berarti modal kerja bersih berpengaruh terhadap profitabilitas dan berarah positif yang ditunjukkan oleh nilai coefficient. Hal ini adanya pengaruh peningkatan penjualan sehingga berpengaruh pada aktiva lancar, dengan adanya naiknya penjualan maka akan berdampak pada profitabilitas yang meningkat pula. Pada tahap decline nilai prob sedikit meningkat dari tahap sebelumnya dengan nilai sebesar 0.0014 dikarenkan pada tahap ini perusahaan mengalami kemunduran maka meningkatnya modal kerja bersih akan sangat berefek pada profitabilitas.

Perusahaan diharuskan menjaga modal kerja yang dapat memberikan keuntungan yaitu jumlah tingginya aktiva lancar dari hutang lancar sehinga dapat meningkatkan profitabilitas Anggarani dan Ficilia, (2014). Kemampuan perusahaan dalam mengoptimalkan investasi dalam modal kerja bersih maka akan mengarah meningkatnya profitabilitas perusahaan. Jika modal kerja bersih tinggi maka akan meningkatkan profitabilitas perusahaan. Apabila perusahaan mengalami kenaikan modal kerja bersih yang disebabkan oleh adanya perubahan yang meningkat dielemen aktiva lancar sehingga akan berdampak pada meningkatnya profitabilitas perusahaan Supriadi \& Puspitasari,( 2012).

Penelitian sebelumnya yang telah dilakukan oleh Tnius, (2018), Herlina \& Nursanah, (2015), dan Supriadi \& Puspitasari, (2012) menguji hubungan modal kerja bersih dengan ROA yang menyatakan bahwa modal kerja bersih berpengaruh signifikan terhadap ROA. 


\section{KESIMPULAN DAN SARAN}

\section{Kesimpulan}

Berdasarkan hasil perhitungan yang telah dilakukan dapat disimpulkan:

1. Perputaran persediaan berpengaruh signifikan terhadap modal kerja bersih. Nilai koefisien menunjukkan arah positif sehingga semakin cepat perputaran persediaan maka semakin tinggi berdampak terhadap peningkatan modal kerja bersih berdasarkan siklus hidup perusahaan pada perusahaan manufaktur yang terdaftar di BEI

2. Perputaran piutang berpengaruh signifikan terhadap modal kerja bersih. Nilai koefisien menunjukkan arah positif sehingga semakin cepat perputaran piutang maka semakin tinggi berdampak terhadap peningkatan modal kerja bersih berdasarkan siklus hidup perusahaan pada perusahaan manufaktur yang terdaftar di BEI. Kecuali, pada tahap decline perputaran piutang tidak memiliki pengaruh terhadap modal kerja bersih.

3. Modal kerja bersih berpengaruh signifikan terhadap profitabilitas. Nilai koefisien menunjukkan arah positif sehingga semakin tinggi modal kerja bersih maka semakin tinggi berdampak terhadap peningkatan profitabilitas berdasarkan siklus hidup perusahaan pada perusahaan manufaktur yang terdaftar di BEI.

\section{Saran}

Saran yang bisa diberikan sebagai berikut:

1. Diharapkan untuk penelitian selajutnya menambah variabel independen seperti perputaran kas dan unsur aktiva lancar lainnya. Selain itu, penelitian selajutnya dapat dilakukan pada perusahaan kelompok industri lainnya.

2. Penelitian ini dapat menjadi pertimbangan bagi perusahaan agar dapat bijak dalam mengelolah perputaran persediaan dan perputaran piutang sehingga modal kerja bersih dan profitabilitas dapat lebih meningkat.

\section{Ucapan Terima Kasih (Acknowledgement)}

Alhamdulilah puji syukur kepada Allah swt, karena kehendak dan ridhaNya peneliti dapat menyelesaikan tesis ini. Tesis ini tidak dapat diselesaikan tanpa bantuan dan bimbingan dari orang - orang yang telah mendukung penulis. Maka dari itu penulis ingin meyampaikan rasa terima kasih kepada Bapak Prof. Dr. Mohamad Adam, S.E., M.E selaku dosen Pembimbing I, ibu Dr. Yuliani, S.E., M.M selaku dosen pembimbing II, dan Ibu Hj. Marlina Widiyanti, S.E., S.H., M.M., Ph selaku penguji dan Ka Prodi MM UNSRI. Terima kasih kepada orang tua dan teman-teman semua yang sudah selalu mendukung dan membantu proses penyelesaian tesis ini.

\section{REFERENSI}

Anggarani, D., \& Ficilia, I. (2014). Analisis Pengaruh Profitabilitas dan Risiko Terhadap Modal Kerja Bersih Pada Perusahaan Tekstil di Bursa Efek Indonesia. Jurnal Manajemen Dan Akuntansi, 3(April), 35-54.

Azizah, S. W. (2017). Pengaruh Manajemen Persediaan dan Manajemen Piutang Terhadap Modal Kerja Perusahaan ( Studi Kasus Pada Perusahaan Manufaktur Sektor Industri Barang Konsumsi yang Terdaftar di BEI ). Jurnal Pendidikan Akuntansi Dan Keuangan, 5(2), 61-70.

Chen, C. (2015). Robust Regression and Outlier Detection with the ROBUSTREG Procedure. SUGI Paper 265-267, SAS Instit(January 2002).

Frielinghaus, A., Mostert, B., \& Firer, C. (2005). Capital structure and the firm 's life stage. Journal Busines Management, 36(4), 9-18. 
Gunawan, C. C., \& Tjun, L. T. (2014). Pengaruh Perputaran Persediaan (Inventory Turnover) dan Perputaran Piutang (Receivables Turnover) Terhadap Gross Profit Margin Perusahaan: Studi Empiris pada Industri Konsumsi yang Listing di Bursa Efek Indonesia Periode 2010 -2013. Jurnal Akuntansi, 6(2), 208-224.

Gup, B. E., \& Agrrawal, P. (1996). Product Life Cycle: A Paradigm for Understanding Financial Management (edisi 6).

Hardianto, A. M. (2014). Pengaruh Perputaran Piutang Terhadap Modal Kerja Pada PT. Pasific Agritama Comodity. Jurnal Bina Bangsa Ekonomika, 07(1), 37-44.

Herlina, \& Nursanah. (2015). Pengaruh Perputaran Modal Kerja Bersih Terhadap Return On Invesment Pada Perusahaan Kosmetik Yang Terdaftar Di Bursa Efek Indonesia. Jurnal Studia Akuntansi Dan Bisnis, 3(1), 45-58.

Horne, J. C. Van, \& John M. Wachowicz, J. (2013). Prinsip - Prinsip Manajemen Keuangan (Edisi 1). Salemba Empat.

Lestiowati, R., \& Pd, S. (2018). Analisis Perputaran Persediaan dan Perputaran Piutang Terhadap Profitabilitas ( Studi Empiris Pada Perusahaan Sektor Makanan dan Minuman yang Terdaftar di Bursa Efek Indonesia Tahun 2014-2016 ). Jurnal Akuntansi, 6(1), 25-39.

Nurdin, N., Raupong, \& Islamiyati, A. (2014). Penggunaan Regresi Robust Pada Data Yang Mengandung Pencilan Dengan Metode Momen. Jurnal Matematika, Statistika \& Komputasi, 10(2), 114-123.

Rahayu, S., Mahsina, \& Wahyuni, S. T. (2017). Analisis Pengaruh Perputaran Persediaan dan Perputaran Piutang Terhadap Modal Kerja Pada PT Unilever Indonesia Tbk. Jurnal Ekonomi Akuntansi, 3(3), 595-603.

Rahman, M. B., \& Widodo, E. (2018). Perbandingan Metode Regresi Robust Estimasi Least Trimmed Square, Estimasi Scale, dan Estimasi Method Of Moment. Jurnal Unnes, 1, 426-433.

Rao \& Gaglani. (2014). Impact of receivables management on working capital : A study on select cement companies. Journal Of Management Research \& Review, 4(6), 651-659.

Reimeinda, V., Murni, S., \& Saerang, I. (2016). Analisis Pengaruh Modal Kerja Terhadap Profitabilitas Pada Industri Telekomunikasi Di Indonesia. Jurnal Berkala Ilmiah Efisiensi, 16(03), 207-218.

Riyanto, A., Raspati, G., Rahayu, Y., \& Prayudi, D. (2019). Implikasi Efisiensi Modal Kerja Terhadap Profitabilitas. Jurnal Muara Ilmu Ekonomi Dan Bisnis, 3(1), 82-91.

Ross, S. A., Westerfield, R. W., \& Jaffe, J. (2013). Fundamentals of Corporate Finance (Edisi 10). New York: McGraw-Hill Irwin.

Sambouw, A. S. (2011). Pengaruh Perputaran Persediaan Dan Perputaran Piutang Terhadap Modal Kerja Pada PT Unilever Tbk. Universitas Komputer Indonesia.

Sertinaria. (2007). Pengaruh Tingkat Perputaran Persediaan Barang Jadi Terhadap Modal Kerja Pada PT. INTI (Persero)"”. Universitas Kompoter Indonesia.

Sofyan, A. F., \& Saifi, M. (2019). Modal Kerja Dan Profitabilitas Pada Perusahaan Food And Beverages ( Studi pada Perusahaan Sub Sektor Food and Beverages yang Terdaftar Di Bursa Efek Indonesia Periode 2014-2018 ). Jurnal Administrasi Bisnis, 73(1), 169-177.

Sulviani, A. (2014). Pengaruh Piutang Terhadap Modal Kerja Pada Perusahaan Manufaktur yang Terdaftar Di Bursa Efek Indonesia (BEI) Periode 2010-2011. Jurnal Ilmiah Manajemen \& Akuntansi, 1(1), 49-64.

Sungkawa, I. (2009). Penditeksian Pencilan (Outlier) Dan Residual Pada Regresi Linier. Jurnal Informatika Pertanian, 18(2), 95-105.

Supriadi, Y., \& Puspitasari, R. (2012). Pengaruh Modal Kerja Terhadap Penjualan dan Profitabilitas Perusahaan pada PT. Indocement Tunggal Prakarsa Tbk. Jurnal Ilmiah 
Kesatuan, 14(1), 71-80.

Tnius, N. (2018). Pengaruh Modal Kerja Terhadap Profitabilitas Pada PT Hanjaya Mandala Sampoerna Tbk. Jurnal Sekuritas, 1(4), 66-79.

Wahyudi, K. D. (2013). Perputaran Piutang dan Pengaruhnya Terhadap Modal Kerja. Jurnal Ilmiah, 1(2), 71-90.

Wijaya, A. L. (2012). Pengaruh Komponen Working Capital Terhadap Profitabilitas Perusahaan. Jurnal Dinamika Akuntansi, 4(1), 20-26. 